\title{
Evaluation of a Real Time PCR Assay Method for the Detection of Genetically Modified Organisms in Food Products
}

\author{
Eleni Spanea ${ }^{1}$, Theofania Tsironi ${ }^{2}$, Efstathia Tsakali ${ }^{1,3}$, Anthimia Batrinou ${ }^{1}$, Valentina Stefanou ${ }^{1}$, Dionisios $^{3}$ \\ Antonopoulos ${ }^{1}$, Stamatios Koussissis ${ }^{1}$, John Tsaknis ${ }^{1}$, Jan Van Impe ${ }^{3} \&$ Dimitra Houhoula $^{1}$ \\ ${ }^{1}$ Department of Food Science and Technology, Faculty of Food Sciences, University of West Attica, Athens, \\ Greece \\ ${ }^{2}$ Laboratory of Food Process Engineering, Department of Food Science and Human Nutrition, Agricultural \\ University of Athens, Athens, Greece \\ ${ }^{3}$ Department of Chemical Engineering, BioTeC+ - Chemical and Biochemical Process Technology and Control, \\ KU Leuven, Gent, Belgium \\ Correspondence: Efstathia Tsakali, BioTeC+- Chemical and Biochemical Process Technology and Control, KU \\ Leuven, Gebroeders De Smetstraat 1, 9000 Gent, Belgium. Tel: 30-699-454-3717. E-mail: \\ efi.tsakali@kuleuven.be
}

Received: April 2, 2019

Accepted: January 3, $2020 \quad$ Online Published: February 15, 2020

doi:10.5539/jfr.v9n2p1

URL: https://doi.org/10.5539/jfr.v9n2p1

\begin{abstract}
The objective of the study was to determine qualitatively by validated Real Time PCR method the occurrence of genetically modified maize and soybean in commercial food products from the Greek market. 70 independent samples were collected, including products from different categories (i.e. cereal based, biscuits and snacks) which declared either corn or soybean on the labelling. The result of the study indicated that $37.1 \%$ of maize and soy products $(n=70)$ displayed in the Greek market have detectable levels of genetically modified maize or soy. These products were identified by specific primers and included common GMO detection primers for $35 \mathrm{~S}$ and NOS terminator. Adequate repeatability and reproducibility was demonstrated for the applied Real Time PCR method, as evaluated by intra- and inter-laboratory tests.
\end{abstract}

Keywords: Reat-Time PCR, GMOs, maize, soybean, 35s promoter, NOS terminator, lectin, zein

\section{Introduction}

\subsection{Genetically Modified Organisms in Food Industry}

The use of genetically modified organisms (GMOs) as foods and food products is becoming more and more widespread. Since the official GMO approval in 1996, adoption of GM technology has been growing exponentially and the number of GM crops introduced to the global market has been increasing. Although the vast amount of GM crops is cultivated outside Europe, the EU is nevertheless faced with the consequent introduction of GM to its market and should respond as foreseen by its legislation (Rosa et al., 2016). Thus, the EU has established a strict regulatory framework to trace GMOs in foods and food ingredients from production to the point of consumption. Once a food product has been found to be positive for one or more GM events (i.e. Roundup Ready ${ }^{\circledR}$ soybean, Bt-176 maize, Bt-11 maize, MON810 maize, and T25 maize), the subsequent analytical steps consist of assessing compliance with the current legislation (EC 1829/2003, EC 1830/2003) and declare labelling as containing GMOs.

\subsection{Explore Importance of the Problem}

The surveillance of food labelling with respect to GMOs requires DNA-based analytical techniques. The methods which can be used to detect GMOs are the polymerase chain reaction (PCR), protein based methods and phenotypic characterization. Among those methods, PCR method is the only one which can provide a general screening for GM varieties. The polymerase chain reaction (PCR) is highly specific and sensitive method for the detection of nucleic acids (DNA or RNA) and a vast number of PCR systems for food control exists, as for example for the detection of pathogenic microorganisms or of food components as well as for the identification of animal species in meat products. PCR also provides a reliable tool for the identification of GMO containing food in order to control food labeling regulations concerning GMOs. Several analytical methods using PCR 
technology have been developed to qualitatively detect or quantitatively determine the presence of a modified sequence of nucleic acid in transgenic food (Gachet, Martin, Vigneau \& Meyer, 1998; Rosa et al., 2016; Wang et al., 2019). A quantitative PCR procedure, which applies the ABI Prism 7700 sequence detection system has been proposed as a more accurate and less labor-intensive method. This procedure is known as TaqMan (Holland et al., 1991) and is based on the application of a fluorogenic probe that hybridizes within the target sequence bound by usual PCR primers (Vaitilingom, Pijnenburg, Gendre \& Bringnon, 1999). The efficiency and operation of the conventional DNA-based assays are still low and are often not adequate for a timely in field testing (Qian, Wang, Wu, Ping, \& Wu, 2018).

\subsection{Evaluation of a PCR Method for Detection of GMOs}

In the present study, a molecular screening method based on Real Time PCR that involves amplification of specific soya or maize sequences from plant DNA and the amplification of 35S promoter and NOS terminator for the detection of GM soya and maize was developed.

\section{Materials and Methods}

\subsection{Food Products}

A total of 70 samples of widely consumed products, namely 40 cereal based products, 10 biscuits, and 20 snacks were collected from the Greek market during the period of September 2018 to February 2019. The samples were separated in 2 categories according to the declarations on their packaging. The first category (category I) included 40 products that were labeled as "it contains corn' ( 25 cereal based products, and 15 snacks) while the second category (category II) included 30 products which bared the indication "it contains soya" (15 cereal based products, 10 biscuits and 5 snacks).

Standard curves were calibrated with commercial transgenic soybean and maize reference standards (Fluka, Buchs, Switzerland). These standards are Certified Reference Material consisting of dried soybean and maize powders and were developed by the Institute for Reference Materials and Measurements (IRMM, Geel, Belgium) for the European interlaboratory trial mentioned above.

\subsection{Genomic DNA Extraction and Quantification}

The suitability of isolated DNA as an analyte for PCR-based detection of GMOs will depend on the quality, purity, and quantity of the DNA. The purity of extracted DNA can be assessed by measurement of $A_{260} / A_{280}$ and $A_{260} / A_{230} \mathrm{UV}$ absorption ratios with a spectrophotometer. When the $260 / 280 \mathrm{~nm}$ absorption ratio is between 1.5 and 2.0 and the 260/230 $\mathrm{nm}$ absorption ratio is more than 1.7 the extracted DNA should be suitable for PCR analysis.

DNA isolation was implemented using the following procedure. NucleoSpin Food kit (Macherey-Nagel, GmbH \& Co. KG, Germany) USA) was used for the DNA extraction of all reference standards and foods. The extraction method was applied according to the manufacturer's instructions with some modifications. Approximately 100 $\mathrm{mg}$ of each sample were used for the extraction, after grinding in liquid nitrogen. The sample was incubated with the Lysis Buffer and the Proteinase-K overnight at $65^{\circ} \mathrm{C}$. After the lysis, the precipitation with absolute Ethanol and the washing steps DNA was eluted in duplicate in order to increase the concentration. DNA concentration

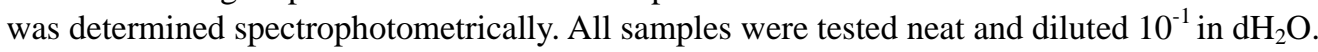

\subsection{Real Time PCR}

\subsubsection{Real Time PCR Assay for Corn and Soya}

The protocol was an in-house established Real Time-PCR assay using the primers of (Brodmann et al. 2002, Studer et al. 1998). Real Time PCR targets were the lectin and zein genes amplifying the $414 \mathrm{bp}$ and 217bp fragments, respectively. Reactions were performed in a $25 \mu \mathrm{L}$ final volume, containing $12.5 \mu \mathrm{L}$ of Master Mix (KAPA SYBR GREEN Fast qPCR, KAPA BIOSYSTEMS), $0.9 \mu \mathrm{M}$ of each primer and $7.5 \mu \mathrm{L}$ of eluted DNA to make up for $25 \mu \mathrm{L}$. Amplification conditions consisted of a $10 \mathrm{~min}$ initial denaturation step at $95^{\circ} \mathrm{C}$, followed by 40 cycles of $15 \mathrm{~s}$ denaturation at $95^{\circ} \mathrm{C}, 60 \mathrm{~s}$ annealing and elongation at $60^{\circ} \mathrm{C}$.

\subsubsection{Real Time PCR Assay for 35S Promoter and NOS Terminator}

The protocol was an in-house established Real Time-PCR assay using the primers of Lipp et al. (1999) and Trapmann et al. (2002) Real Time PCR targets the 35S promoter and the NOS terminator genes amplifying a $180 \mathrm{bp}$ and a $83 \mathrm{bp}$ fragment respectively. Reactions were performed in a $25 \mu \mathrm{L}$ final volume, containing $12.5 \mu \mathrm{L}$ of Master Mix (KAPA SYBR GREEN Fast qPCR, KAPA BIOSYSTEMS). $0.9 \mu \mathrm{M}$ of each primer, and $7.5 \mu \mathrm{L}$ of eluted DNA to make up for $25 \mu \mathrm{L}$. Amplification conditions consisted of a $10 \mathrm{~min}$ initial denaturation step at $95^{\circ} \mathrm{C}$, followed by 40 cycles of $15 \mathrm{~s}$ denaturation at $95^{\circ} \mathrm{C}, 60 \mathrm{~s}$ annealing and elongation at $60^{\circ} \mathrm{C}$. 


\subsubsection{Standard Curves for Real-Time PCR Analysis}

The Step One plus ${ }^{\mathrm{TM}}$ RT-PCR System (Applied Biosystems) was used for the PCR assay. RT fluorescence measurements were compiled in every cycle. All reactions included negative controls containing the amplification master mix and $\mathrm{dH}_{2} \mathrm{O}$ that was used for reagent preparation.

For positive controls and DNA quantification, a standard curve was designed using known concentrations (KC) of DNA extracted from $2 \%$ transgenic maize or soybean $\left(\mathrm{KC}_{1}=70 \mathrm{ng} / 100 \mathrm{mg}\right.$ of food, $\mathrm{KC}_{2}=7.0 \mathrm{ng} / 100 \mathrm{mg}$ of food, $\mathrm{KC}_{3}=0.7 \mathrm{ng} / 100 \mathrm{mg}$ of food, $\mathrm{KC}_{4}=70 \mathrm{pg} / 100 \mathrm{mg}$ of food, $\mathrm{KC}_{5}=7.0 \mathrm{pg} / 100 \mathrm{mg}$ of food, $\mathrm{KC}_{6}=700 \mathrm{fg} / 100$ $\mathrm{mg}$ of food. A cycle threshold value $(\mathrm{Ct})$ was defined as the cycle of the RT-PCR at which a significant fluorescence increases in comparison to the negative control and the blanks were detected; this increase is associated with an exponential growth of PCR product during the log-linear phase. RT-PCR runs were acceptable only when the negative control had an undetectable $\mathrm{Ct}$, the $\mathrm{KC}_{2}$ and $\mathrm{KC}_{3}$ had $\mathrm{Cts}$ between 25 and 27, and the efficiency of the PCR was 90-100\%. The intrinsic detection limit of the improved method was $0.007 \mathrm{ng}(\mathrm{Ct}=32)$. The samples were characterized as negative with a higher $\mathrm{Ct}$. All samples were tested neat and diluted $10^{-1}$ in $\mathrm{dH}_{2} \mathrm{O}$ for the detection of inhibition. Inhibition was defined as a positive PCR result with a diluted specimen, while a negative PCR result was obtained with the specimen tested undiluted.

\subsubsection{Repeatability and Reproducibility of Assays}

In order to evaluate the repeatability and reproducibility of the method, 5 samples at a concentration of $1.5 \mathrm{ng} / \mu \mathrm{L}$ were randomly chosen as PCR templates and amplified in triplicate in an experiment performed 3 times.

\section{Results and Discussion}

\subsection{Real Time PCR Assay}

The specificity of the primer pair was confirmed by Real Time PCR amplification of the peanuts, sesame and hazelnut kernels which were used as negative controls. No amplification signal was observed for any of them even at threshold cycle (CT) values higher than 35. All five levels positive controls (serial dilutions) produced fluorescence curves except the blank control. Real Time-PCR runs were acceptable only when the negative control had an undetectable $\mathrm{Ct}$, and the positive controls had Cts between 25 and 27, and the efficiency of the PCR was $90-100 \%$.

\subsection{Repeatability and Reproducibility of Assays}

The results of the assay showed that the coefficient of variation values for both intra-experimental and inter-experimental data ranged from 0.45 to $0.80 \%$ and 0.23 to $0.71 \%$, respectively (Table 1 ). These results indicate that $\mathrm{Ct}$ measurements were highly reproducible and repeatable, demonstrating the applicability of Real-Time PCR method for the qualitative detection of GMOs.

Table 1. Coefficient of variation values for intra- and inter-experimental test results of 5 randomly chosen samples

\begin{tabular}{lllllllll}
\hline & Experiment 1 & \multicolumn{2}{c}{ Experiment 2 } & \multicolumn{2}{c}{ Experiment 3 } & \multicolumn{2}{c}{ Intra-experimental } \\
\hline Sample & Mean Ct & CV \% & Mean Ct & CV\% & Mean Ct & CV\% & Mean Ct & CV\% \\
\hline 1 & $25.72 \pm 0.15$ & 0.58 & $25.45 \pm 0.18$ & 0.71 & $25.68 \pm 0.10$ & 0.39 & $26.89 \pm 0.12$ & 0.45 \\
2 & $24.74 \pm 0.10$ & 0.40 & $24.00 \pm 0.08$ & 0.33 & $26.10 \pm 0.12$ & 0.46 & $24.98 \pm 0.20$ & 0.80 \\
3 & $25.99 \pm 0.08$ & 0.31 & $24.45 \pm 0.15$ & 0.61 & $25.38 \pm 0.18$ & 0.71 & $26.58 \pm 0.16$ & 0.60 \\
4 & $26.57 \pm 0.06$ & 0.23 & $26.95 \pm 0.20$ & 0.74 & $25.52 \pm 0.15$ & 0.59 & $25.99 \pm 0.18$ & 0.69 \\
5 & $26.01 \pm 0.14$ & 0.54 & $26.45 \pm 0.18$ & 0.68 & $26.58 \pm 0.20$ & 0.75 & $25.75 \pm 0.15$ & 0.58 \\
\hline
\end{tabular}

\subsection{Food Testing}

Qualitative PCR-based methods were used to evaluate genetically modified maize and soya products sold commercially in the Attica region (Greece). The majority of the tested samples were maize products, as indicated in Tables 1-3. Both maize and soya foods were mainly cereal based foods, followed by snacks and biscuits.

By using the Real Time PCR method for the identification of lectin gene of soya, all 30 products containing soya were positive and all 40 corn samples were negative. Furthermore, all 40 corn products declared to contain corn were found positive amplifying the maize gene. The analytical sensitivity and specificity was $100 \%$ for both genes. In the first category of the corn-based products $(n=40), 10$ samples $(25 \%)$ (8 from cereal based products and 2 from snacks) were positive when amplified by the $35 \mathrm{~S}$ promoter primer, which is specific to the $35 \mathrm{~S}$ promoter originating from CaMV virus used in genetically modified plants and 3 samples (7.5\%) from cereal 
based products were detected with both the $35 \mathrm{~S}$ and the NOS Terminator primer. In total, $13(32.5 \%)$ events of genetic modification (either $35 \mathrm{~S}$ or NOS terminator) were detected in the corn-based samples (Table 2).

In the second category of the soya-based products $(n=30), 8$ samples $(26.7 \%)$ all from cereal based products were amplified by the $35 \mathrm{~S}$ promoter primer and 5 samples (16.7\%) were amplified both by the $35 \mathrm{~S}$ and the NOS Terminator primer. In total, $13(43.3 \%)$ events of genetic modification (either $35 \mathrm{~S}$ or NOS terminator) were detected in soya samples (Table 2). Overall, in all analyzed samples $(n=70)$, a total of 26 events of genetic modification (37.1\%) were detected by RT-PCR corresponding to 18 products $(25.7 \%)$. From the 26 genetically modified events detected $24(92.3 \%)$ were from cereal based products and 2 (7.6\%) from the snacks category.IThe $35 \mathrm{~S}$ promoter, a sequence from a cauliflower virus, and the NOS terminator, a sequence from a plant bacterium (Agrobacterium tumefaciens), are commonly used as regulation sites, i.e., the "on" and "off" switches for the newly inserted genes. They are present in virtually all genetically modified plants, so most screening methods search for these sequences. Semi-quantitative tests will detect GMOs and compare them to external reference standards of known GMO concentration, with a detection limit of $0.1 \%$. Real-time polymerase chain reaction (PCR) is used for greater accuracy in quantitation and has a detection limit of $0.01 \%$. (Hardegger, Brodmann \& Herrmann, 1999)

Table 2. Food product types and GMOs detection indicated by the amplification of 35S promoter and NOS terminator by RT-PCR

\begin{tabular}{|c|c|c|c|c|c|c|c|}
\hline $\begin{array}{l}\text { Food } \\
\text { product } \\
\text { category }\end{array}$ & $\begin{array}{l}\text { No. of } \\
\text { tested } \\
\text { products }\end{array}$ & $\begin{array}{l}\text { declared } \\
\text { "contain } \\
\text { corn" }\end{array}$ & $\begin{array}{l}\text { amplified of } \\
35 \mathrm{~S} \\
\text { promoter }\end{array}$ & $\begin{array}{l}\text { amplified of } \\
\text { NOS } \\
\text { terminator }\end{array}$ & $\begin{array}{l}\text { declared } \\
\text { "contain } \\
\text { soya" }\end{array}$ & $\begin{array}{l}\text { amplified of } \\
35 \mathrm{~S} \\
\text { promoter }\end{array}$ & $\begin{array}{l}\text { amplified of } \\
\text { NOS } \\
\text { terminator }\end{array}$ \\
\hline Cereals & 40 & 25 & 8 & 3 & 15 & 8 & 5 \\
\hline Biscuits & 10 & - & - & - & 10 & - & - \\
\hline Snacks & 20 & 15 & 2 & - & 5 & - & - \\
\hline Total & 70 & 40 & 10 & 3 & 30 & 8 & 5 \\
\hline
\end{tabular}

Table 3. Analytical results of the positive samples for RT-PCR assay of the corn specimens that amplified the $35 \mathrm{~S}$ promoter or NOS Terminator

\begin{tabular}{|c|c|c|c|c|c|}
\hline \multirow[t]{2}{*}{ No } & \multirow[t]{2}{*}{ Specimen } & \multirow{2}{*}{$\begin{array}{l}\text { RT-PCR } \\
35 \mathrm{~S}\end{array}$} & \multicolumn{2}{|r|}{ RT-PCR } & \multirow[b]{2}{*}{$\begin{array}{l}\text { Ct Mean Value } \\
\text { for positive samples }\end{array}$} \\
\hline & & & $\begin{array}{l}\text { RT-PCR } \\
\text { NOS }\end{array}$ & $\begin{array}{l}\text { DNA yield (ng/100 mg food) } \\
\text { Mean Value }\end{array}$ & \\
\hline 1 & Corn flakes & Positive & Positive & 0.784 & 25.00 \\
\hline 2 & $\begin{array}{l}\text { Corn flakes } \\
\text { with fruits }\end{array}$ & Positive & Negative & 0.535 & 26.10 \\
\hline 3 & $\begin{array}{l}\text { Corn flakes } \\
\text { with chocolate }\end{array}$ & Positive & Negative & 0.183 & 27.32 \\
\hline 4 & $\begin{array}{l}\text { Corn flakes } \\
\text { with nuts }\end{array}$ & Positive & Negative & 0.655 & 26.00 \\
\hline 5 & Corn flakes 2 & Positive & Positive & 0.432 & 26.80 \\
\hline 6 & Corn flakes bar1 & Positive & Negative & 0.122 & 27.12 \\
\hline 7 & Corn flakes bar2 & Positive & Negative & 0.235 & 26.80 \\
\hline 8 & Corn flakes 3 & Positive & Positive & 0.635 & 26.00 \\
\hline 9 & Snack 1 & Positive & Negative & 0.056 & 28.58 \\
\hline 10 & Snack 2 & Positive & Negative & 0.068 & 28.00 \\
\hline
\end{tabular}


Table 4. Analytical results of the positive samples for RT-PCR assay of the soya specimens that amplified the $35 \mathrm{~S}$ or the NOS promoter

\begin{tabular}{|c|c|c|c|c|c|}
\hline \multirow[t]{2}{*}{ No } & \multirow[t]{2}{*}{ Specimen } & \multirow{2}{*}{$\begin{array}{l}\text { RT-PCR } \\
35 \mathrm{~S}\end{array}$} & \multicolumn{2}{|r|}{ RT-PCR } & \multirow[b]{2}{*}{$\begin{array}{l}\text { Ct Mean Value } \\
\text { for positive samples }\end{array}$} \\
\hline & & & $\begin{array}{l}\text { RT-PCR } \\
\text { NOS }\end{array}$ & $\begin{array}{l}\text { DNA yield } \\
\text { (ng/100 mg food) } \\
\text { Mean Value }\end{array}$ & \\
\hline 1 & Cereal flakes with soya 1 & Positive & Positive & 1.00 & 25.00 \\
\hline 2 & Cereal flakes with soya 2 & Positive & Positive & 0.910 & 25.30 \\
\hline 3 & Cereal flakes with soya 3 & Positive & Positive & 0.900 & 25.60 \\
\hline 4 & Cereal flakes with soya and nuts 1 & Positive & Positive & 0.956 & 26.00 \\
\hline 5 & Cereal flakes with soya and nuts 2 & Positive & Negative & 0.832 & 26.80 \\
\hline 6 & Cereal flakes with soya and chocolate 1 & Positive & Negative & 0.125 & 27.12 \\
\hline 7 & Cereal flakes with soya and chocolate 2 & Positive & Negative & 0.235 & 26.80 \\
\hline 8 & Cereal flakes with soya and nuts 3 & Positive & Positive & 0.635 & 26.00 \\
\hline
\end{tabular}

The amplicons of the specific sequences detected have been used in the literature to build the different GMOs and regulate expression of transgenes, such as promoter 35S and the terminator NOS (Gachet et al, 1998; Spegelhalter, Lauter \& Russell, 2001; van Duijn et al., 2002; Forte et al., 2005; Vijayakumar, Martin, Gowda \& Prakash, 2009; Fu et al., 2015). The transgenic content of four commercial food products (maize starch, muesli, lecithin and soybean proteins) has been determined by Vaitilingom et al. (1999), with the aim to quantify the percentage of "Maximizer" maize and "Roundup Ready" soybean in food products. In the present study, Real Time PCR detected adequately GM maize and soybean food products displayed in the Greek market.

\section{Conclusions}

The current legislation that regulates the presence of GMOs in crops, foods and ingredients, necessitates the development of reliable and sensitive methods for GMO detection in foods. The objective of the present study was to determine qualitatively by validated PCR methods the occurrence of genetically modified maize and soybean in commercial food products from the Greek market. The result of the study indicated that 26 events of genetic modification $(37.1 \%, n=70)$ were detected by RT-PCR in all analyzed maize and soy products displayed in the Greek market. These products were identified by specific primers and included common GM detection primers for $35 \mathrm{~S}$ and NOS terminator. The detection of GMOs in more than one third of the investigated food products available in the Greek market indicates the high importance of a qualitative detection system to determine the presence of GMOs in foods. Such real-time screening method could be convenient for the user and applicable to a wide range of food systems. There is a need for a reasoned and rational approach to the benefits of genetically modified foods, as well as consideration of the rights of consumers to know what is in their food. Demand for testing GMOs and for certifying non-GMO foodstuffs has increased dramatically. GMO testing is needed as a precursor to promoting high standards of regulation tracking developments, acting on new evidence and instituting population health.

\section{Acknowledgments}

This study was supported by the Fund for Scientific Research FWO-Vlaanderen (grant G.0863.18) and by the KU Leuven Research Fund (Center of Excellence OPTEC-Optimization in Engineering and project C24/18/046).

\section{References}

Brodmann, P. D., Ilg, E. C., Berthoud, E., \& Herrmann, A. (2002). Real-Time Quantitative Polymerase Chain Reaction Methods for Four Genetically Modified Maize Varieties and Maize DNA. Food Journal of AOAC International, 85(3), 646-653.

Forte, V. T., Di-Pinto, C., Martino, C., Tantillo, G. M., Grasso, G., \& Schena, F. P. (2005). A general multiplex-PCR assay for the general detection of genetically modified soya and maize. Food Control, 16, 535-539. https://doi.org/10.1016/j.foodcont.2004.05.010

Fu, W., Zhu, P., Wang, C., Huang, K., Du, Z., Tian, W., Wang, Q., Wang, H., Xu, W., \& Zhu, S. (2015). A highly sensitive and specific method for the screening detection of genetically modified organisms based on digital PCR without pretreatment. Scientific reports, 5, 12715. https://doi.org/10.1038/srep12715

Gachet, E., Martin, G. G., Vigneau, F., \& Meyer, G. (1998). Detection of genetically modified organisms(GMOs) by PCR: a brief review of methodologies available. Trends in Food Science and Technology, 9, 380-388. 
https://doi.org/10.1016/S0924-2244(99)00002-3

Hardegger, M., Brodmann, P., \& Herrmann, A. (1999). Quantitative detection of the 35S promoter and the NOS terminator using quantitative competitive PCR. European Food Research and Technology, 209(2), 83-87. https://doi.org/10.1007/s002170050462

Holland, P. M., Abramson, R. D., Watson, R., \& Gelfand, D. H. (1991). Detection of specific polymerase chain reaction product by utilizing the $5 \phi-3 \phi$ exonuclease activity of Thermus aquaticus DNA polymerase. Proceedings of the National Academy of Sciences of the United States of America, 88, 7276-7280. https://doi.org/10.1073/pnas.88.16.7276

Lipp, M., Brodmann, P., Pietsch, K., Pauwels, J., Anklam, E., Börchers, T., ... Wurtz, A. (1999) IUPAC collaborative trial study of a method to detect genetically modified soy beans and maize in dried powder. Journal of AOAC International, 82(4), 923-928.

Qian, C., Wang, R., Wu, H., Ping, J., \& Wu, J. (2018). Recent advances in emerging DNA-based methods for genetically modified organisms (GMOs) rapid detection. TrAC Trends in Analytical Chemistry, 109, 19-31. https://doi.org/10.1016/j.trac.2018.09.021

Rosa, S. F., Gatto, F., Angers-Loustau, A., Petrillo, M., Kreysa, J., \& Querci, M. (2016). Development and applicability of a ready-to-use PCR system for GMO screening. Food Chemistry, 201, 110-119. https://doi.org/10.1016/j.foodchem.2016.01.007

Spiegelhalter, F., Lauter, F. R., \& Russell, J. M. (2001). Detection of genetically modified food products in a commercial laboratory. Journal of Food Science, 66(5), 634-640. https://doi.org/10.1111/j.1365-2621.2001.tb04613.x

Studer, E., Rhyner, C., Lüthy, J., \& Hübner, P. (1998). Quantitative competitive PCR for the detection of genetically modified soybean and maize. Zeitschrift für Lebensmitteluntersuchung und -Forschung A, 207(3), 207-213. https://doi.org/10.1007/s002170050320

Trapmann, S., Schimmel, H., Kramer, G. N., Van de Eede, G., \& Pauwels, J. (2002). Production of Certified Reference Materials for the Detection of Genetically Modified Organisms. Journal of AOAC International, 85(3), 775-779.

Vaïtilingom, M., Pijnenburg, H., Gendre, F., \& Bringnon, P. (1999). Reat-Time quantitative PCR detection of genetically modified maximizer and roundup ready soybean in some representative foods. Journal of Agricultural and Food Chemistry, 47, 5261-5266. https://doi.org/10.1021/jf981208v

van Duijn, G., van Biert, R., Bleeker-Marcelis, H., van Boeijen, I., Adan, A. J., Jhakrie, S., \& Hessing, M. (2002). Detection of genetically modified rganisms in foods by protein- and DNAbased techniques: Bridging the methods. Journal of AOAC International, 85(3), 787-791.

Vijayakumar, K. R., Martin, A., Gowda, L. R., \& Prakash, V. (2009). Detection of genetically modified soya and maize: Impact of heat processing. Food Chemistry, 117, 514-521.

https://doi.org/10.1016/j.foodchem.2009.04.028

Wang, X., Tang, T., Miao, Q., Xie, S., Chen, X., Tang, J., Peng, C., Xu, X., Wei, W., You, Z., \& Xu, J. (2019). Detection of transgenic rice line TT51-1 in processed foods using conventional PCR, real-time PCR, and droplet digital PCR. Food Control, 98, 380-388. https://doi.org/10.1016/j.foodcont.2018.11.032

\section{Copyrights}

Copyright for this article is retained by the author(s), with first publication rights granted to the journal.

This is an open-access article distributed under the terms and conditions of the Creative Commons Attribution license (http://creativecommons.org/licenses/by/4.0/). 